\title{
Natural events of anoxia and low respiration index in oligotrophic lakes of the Atlantic Tropical Forest
}

\author{
H. Marotta ${ }^{1}$, M. L. S. Fontes ${ }^{2}$, and M. M. Petrucio ${ }^{2}$ \\ ${ }^{1}$ Physical Geography Laboratory (LAGEF/UFF), Department of Geography, Institute of Geosciences, Fluminense Federal \\ University, 24210-340, Niterói, RJ, Brazil \\ ${ }^{2}$ Laboratory of Freshwater Ecology (LIMNOS/UFSC), Department of Ecology and Zoology, Center of Biological Science, \\ Santa Catarina Federal University, 88040-900, Florianópolis, SC, Brazil
}

Correspondence to: H. Marotta (humbertomarotta@id.uff.br)

Received: 14 March 2012 - Published in Biogeosciences Discuss.: 3 April 2012

Revised: 19 June 2012 - Accepted: 29 June 2012 - Published: 1 August 2012

\begin{abstract}
Hypoxia is a well-recognized condition reducing biodiversity and increasing greenhouse gas emissions in aquatic ecosystems, especially under warmer temperatures of tropical waters. Anoxia is a natural event commonly intensified by human-induced organic inputs in inland waters. Here, we assessed the partial pressure of $\mathrm{O}_{2}\left(p \mathrm{O}_{2}\right)$ and $\mathrm{CO}_{2}$ $\left(p \mathrm{CO}_{2}\right)$, and the ratio between them (represented by the respiration index, RI) in two oligotrophic lakes of the Atlantic Tropical Forest, encompassing dry and rainy seasons over 19 months. We formulated the hypothesis that thermal stratification events could be coupled to natural hypoxia in deep waters of both lakes. Our results indicated a persistence of $\mathrm{CO}_{2}$ emissions from these tropical lakes to the atmosphere, on average \pm standard error (SE) of $17.4 \mathrm{mg} \mathrm{C} \mathrm{m}^{-2} \mathrm{~h}^{-1}$ probably subsided by terrestrial $\mathrm{C}$ inputs from the forest. Additionally, the thermal stratification during the end of the dry season and the rainy summer was coupled to anoxic events and very low RI in deep waters, and to significantly higher $p \mathrm{O}_{2}$ and $\mathrm{RI}$ at the surface (about $20000 \mu \mathrm{atm}$ and 1.0, respectively). In contrast, the water mixing during dry seasons at the beginning of the winter was related to a strong destratification in $p \mathrm{O}_{2}, p \mathrm{CO}_{2}$ and $\mathrm{RI}$ in surface and deep waters, without reaching any anoxic conditions throughout the water column. These findings confirm our hypothesis, suggesting that lakes of the Atlantic Tropical Forest could be dynamic, but especially sensitive to organic inputs. Natural anoxic events indicate that tropical oligotrophic lakes might be highly influenced by human land uses, which increase organic discharges into the watershed.
\end{abstract}

\section{Introduction}

Lakes are small but broadly distributed at low altitudes (Downing et al., 2006), representing a common fate for organic and inorganic inputs from large areas in the watershed (Tranvik et al., 2009). These ecosystems show intense metabolic activity supported by the availability of water, nutrients and organic matter in both pelagic (Biddanda et al., 2001) and benthic (Downing et al., 2008) compartments. Globally, important pool of carbon (C) fixed in organic compounds by terrestrial plants may be buried (von Wachenfeldt and Tranvik, 2008) or mineralized to $\mathrm{C}$ gases (Cole et al., 2007) within lakes, a crucial component of the $C$ cycle.

Oxygenic photosynthesis and aerobic respiration are the major metabolic pathways by which organic matter is produced and destroyed in the biosphere (Cole et al., 2000), corresponding to the overall metabolic balance of an ecosystem (Howarth et al., 1996). Carbon dioxide $\left(\mathrm{CO}_{2}\right)$ and oxygen $\left(\mathrm{O}_{2}\right)$ are metabolic gases involved in both processes, as oxygenic photosynthesis absorbs $\mathrm{CO}_{2}$ producing $\mathrm{O}_{2}$, while aerobic respiration demands $\mathrm{O}_{2}$ releasing $\mathrm{CO}_{2}$ (Clarke and Fraser, 2004). In this way, lakes may show net autotrophy uptaking atmospheric $\mathrm{CO}_{2}$, or net heterotrophy with subsequent $\mathrm{CO}_{2}$ evasion to atmosphere. However, most lakes are heterotrophic due to terrestrial organic inputs subsiding the aquatic decomposition (Duarte and Prairie, 2005; Cole et al., 1994) and food web (Pace et al., 2004).

Respiration is the most efficient biological process of organic degradation, but is strongly limited by the $\mathrm{O}_{2}$ supply (Sobek et al., 2009). The $\mathrm{O}_{2}$ depletion following high 
respiration of the excessive organic loading is a typical cause of organism death and severe decline in the species (VaquerSunyer and Duarte, 2008), which also stimulates the anaerobic organic decomposition in natural waters (Conrad et al., 2011). These anaerobic processes have important implications to global warming, producing more powerful greenhouse gases than $\mathrm{CO}_{2}$ (Bastviken et al., 2011), as well to create "dead zones" by releasing toxic substances for major aquatic organisms (Diaz and Rosenberg, 2008). Besides aerobic conditions (Diaz and Rosenberg, 2008; Vaquer-Sunyer and Duarte, 2008), the high ratio between partial pressures of $\mathrm{O}_{2}$ and $\mathrm{CO}_{2}\left(p \mathrm{O}_{2}: p \mathrm{CO}_{2}\right)$, named respiration index (RI), is also crucial to support biological diversity, as it provides a simple numerical constraint related to available energy in natural waters (Brewer and Peltzer, 2009).

Along the latitudinal gradient, warmer annual temperatures in ecosystems may contribute to higher diversity of organisms (Amarasinghe and Welcomme, 2002) and more intense metabolic processes (Brown et al., 2004; Davidson and Janssens, 2006), including those involved in the organic mineralization with subsequent production of greenhouse gases (Marotta et al., 2009a; Bastviken et al., 2010). The magnitude of metabolic responses following common changes in resource availability or conditions may be substantially enhanced under higher temperatures, resulting in a high variability either among (Marotta et al., 2009a) or within tropical lakes (Marotta et al., 2010a) and over time in these ecosystems (Marotta et al., 2010a, b).

The Atlantic Tropical Forest is a very productive and threatened biome in Brazil (Metzker et al., 2011). Lakes surrounded by this forest show a persistent $\mathrm{CO}_{2}$ evasion to the atmosphere attributable to terrestrial C inputs (Marotta et al., 2009b), despite large changes related to seasonal events of water stratification and mixing, especially during the summer and winter, respectively (Tundisi, 1997). The aim of the present study was to assess $p \mathrm{O}_{2}, p \mathrm{CO}_{2}$ and RI fluctuations following seasonal water column stratification and mixing periods over 19 months in two oligotrophic lakes of the Atlantic Tropical Forest. We tested the hypothesis that thermal stratification events could be coupled to natural hypoxia in deep waters of both lakes.

\section{Material and methods}

\subsection{Study area}

Barra $\left(19^{\circ} 47^{\prime} 45^{\prime \prime} \mathrm{S} ; \quad 42^{\circ} 36^{\prime} 53^{\prime \prime} \mathrm{W}\right)$ and Aguapé $\left(19^{\circ} 51^{\prime} 32^{\prime \prime} \mathrm{S} ; 42^{\circ} 38^{\prime} 32^{\prime \prime} \mathrm{W}\right)$ are lakes situated relatively close to one another (distance $6 \mathrm{~km}$ ) at $300-\mathrm{m}$ altitude on the southern border of the Rio Doce State Park (Southeast Brazil; Fig. 1). This protected area includes one of most important conserved remnant of the Atlantic Tropical Forest in Brazil (36000 ha). Lake Barra and Lake Aguapé are shallow (maximal depth of $10 \mathrm{~m}$ ) and small (areas of

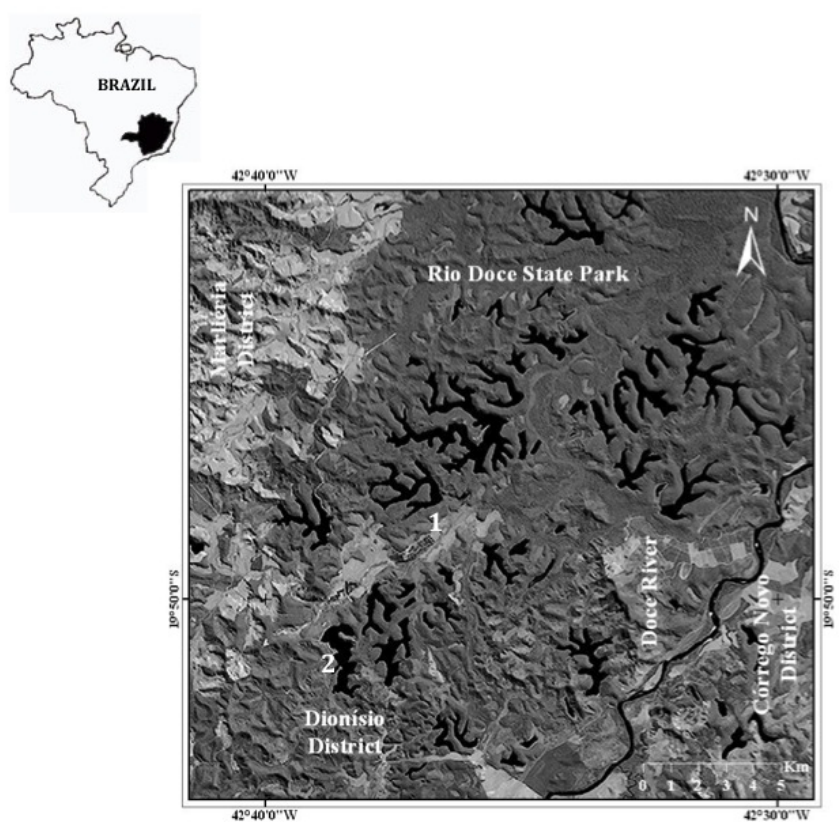

Fig. 1. Geographic locations of the studied lakes surrounded by Atlantic Tropical Forest in Southeast Brazil: (1) Lake Barra and (2) Lake Aguapé.

1350 and $1372 \mathrm{~km}^{2}$, respectively), showing organic and oligotrophic waters (total phosphorus around $1 \mu \mathrm{mol} 1^{-1}$, chlorophyll $a$ about $15 \mu \mathrm{g} \mathrm{l}^{-1}$, and dissolved organic carbon above $5 \mathrm{mg} \mathrm{l}^{-1}$ during this study). Despite any human interference in the margins (abandoned eucalyptus plantation in regeneration to native forest and few field houses), both lakes receive natural inputs from the watershed dominated by the Atlantic Tropical Forest with low human use and preserved natural conditions. Terrestrial inputs from the protected tropical forest commonly affect aquatic organisms and metabolic processes in lakes of this region (Petrucio and Barbosa, 2004; Petrucio et al., 2006).

The climate of the study area is tropical wet and dry (Köppen climate classification Aw; Peel et al., 2007), characterized by a strong seasonality in rainfall (Metzker et al., 2011). This includes dry winters from June to September and rainy summers from December to March showing 25yr monthly mean precipitation ( \pm SE) around, respectively, $10( \pm 2)$ and $198( \pm 13) \mathrm{mm}$ (data of the National Institute of Meteorology for 1987-2011). Lakes of this region show a well-described seasonal stratification during the rainy season, caused by less water circulation, higher air temperatures and inputs of slightly colder and denser groundwaters, contrasting with a typical mixing during the dry winter by lower air temperatures and more windy conditions (Tundisi, 1997).

\subsection{Study design}

Water samples for $\mathrm{O}_{2}, \mathrm{pH}$, alkalinity, temperature, nutrients, chlorophyll $a$ and dissolved organic carbon (DOC) were 
collected in the morning, using a 3-1 Van Dorn bottle, at approximately monthly intervals from March 2004 to October 2005 (19 months). Additionally, one daily variation in $\mathrm{O}_{2}, \mathrm{pH}$, alkalinity and temperature without any nocturnal data (time of sampling at 24:00, 18:00, 06:00 and 24:00 LT the day after) was simultaneously assessed in three periods: (a) rainy season at the end of the summer (March 2005), (b) dry season at the beginning of the winter (June 2005) and (c) dry season at the end of the winter (September 2005). Four sampling depths at the central station in both lakes were chosen assuming the light penetration by a $20-\mathrm{cm}$ diameter Secchi disk: $100 \%$ (surface waters), $10 \%$ (the Secchi depth), $1 \%$ (three times the Secchi depth), and $0 \%$ (aphotic zone below the $1 \%$ light penetration depth and above the bottom sediment).

\subsection{Analytical methods}

Dissolved $\mathrm{O}_{2}$ concentrations by the Winkler method, $\mathrm{pH}$ using a pH meter Marconi PA-200 (precision of 0.01 unities of $\mathrm{pH}$ ), and the total alkalinity by the Gran titration were immediately analyzed after the sampling (APHA, 1992). At the laboratory, pre-filtered $(0.7 \mu \mathrm{m}$, Whatman $\mathrm{GF} / \mathrm{F})$ water samples were analyzed for chlorophyll $a$ concentrations by extraction with $90 \%$ acetone (Lorenzen, 1967), and for DOC concentrations by high-temperature catalytic oxidation using a TOC-5000A Shimadzu Analyzer (samples pre-acidified to $\mathrm{pH}<2.0$ ).

$\mathrm{CO}_{2}$ concentrations were estimated from measurements of pH and alkalinity (Stumm and Morgan, 1996) with corrections for temperature, altitude, and ionic strength (Cole et al., 1994). $p \mathrm{CO}_{2}$ and $p \mathrm{O}_{2}$ were calculated from the Henry's law with appropriated adjustments for temperature and salinity for $\mathrm{CO}_{2}$ (Weiss, 1974) and $\mathrm{O}_{2}$ (Garcia and Gordon, 1992) solubility. The respiration index was calculated as the ratio $p \mathrm{O}_{2}: p \mathrm{CO}_{2}$ in $\log 10$ following Brewer and Peltzer (2009). Negative values of RI $(\mathrm{RI}<0)$ indicate a ratio $p \mathrm{O}_{2}: p \mathrm{CO}_{2}<1.0$.

\subsection{Statistical analyses}

Log-transformed data of $p \mathrm{O}_{2}$ and $p \mathrm{CO}_{2}$ or raw data of RI from the same sampling depth or period for each lake showed significant Gaussian distribution (KolmogorovSmirnov, $p<0.05$ ), homogeneity of variances (Bartlett, $p>$ $0.05)$ and significant matching (F test, $p<0.05$ ). Hence, these variables in different sampling depths and periods were compared using parametric tests (Zar, 1996), repeated measures of one-way ANOVA followed by Tukey-Kramer multiple comparisons (significance level set at $p<0.05$ ). In contrast, non-parametric statistics were used to test for differences in $p \mathrm{O}_{2}, p \mathrm{CO}_{2}$ and $\mathrm{RI}$ between the lakes, repeated measures of Friedman test followed by Dunn's post-test (significance level set at $p<0.05$ ), as the transformed data set including all measurements of each variable from the same
(A)
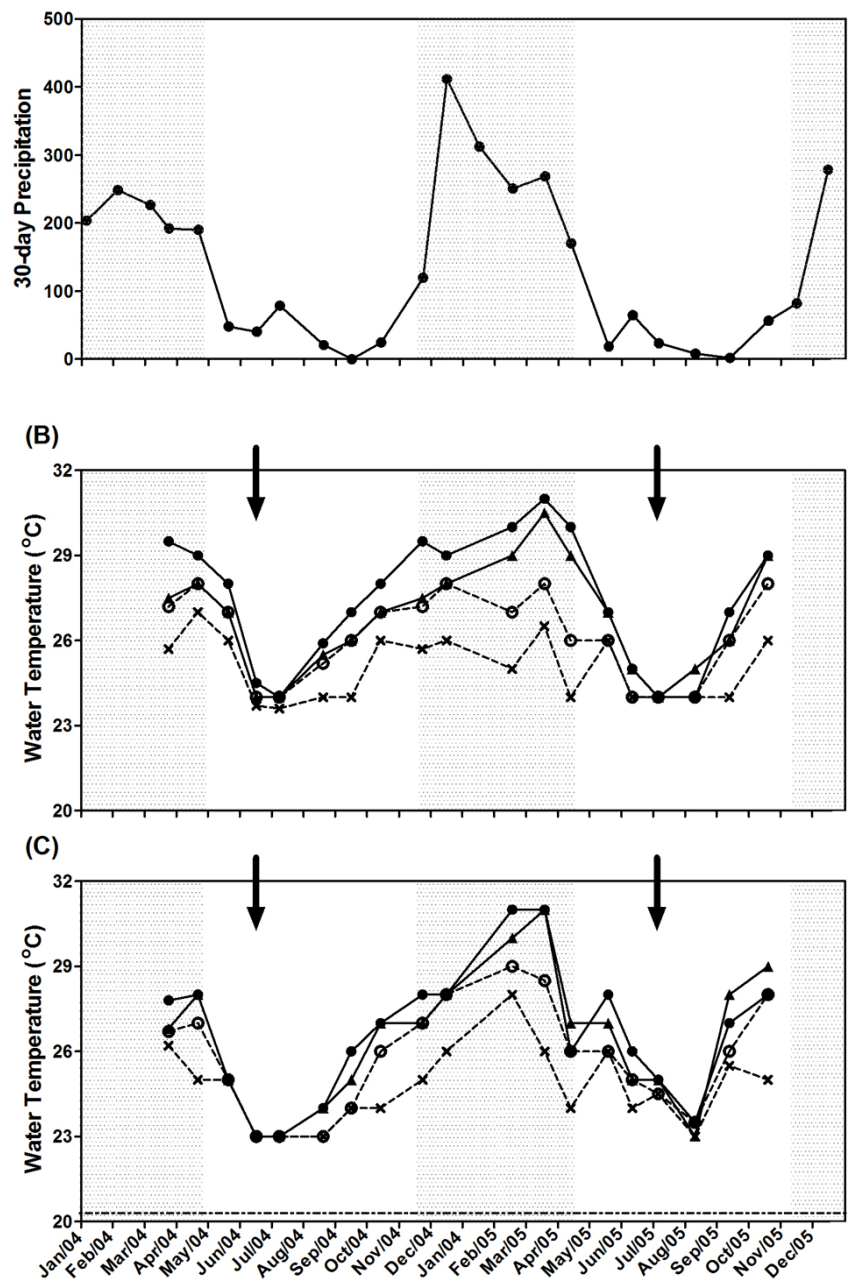

Fig. 2. Monthly fluctuations in 30-day precipitation (A) and water temperature in Lake Barra (B) and Lake Aguapé (C) during 19 months from March 2004 to October 2005. Four depths were sampled in the morning assuming the light penetration in lake waters: $100 \%$ (unbroken line, filled circle), $10 \%$ (unbroken line, filled triangle), $1 \%$ (dashed line, open circle), and $0 \%$ (dashed line, crosses). See material and methods for details on the determination of each sampling depth. Arrows point to the thermal mixing events during the dry season at the beginning of the winter (2004 and 2005), and the dotted frames indicate the rainy seasons (between 2004 and 2005) in each lake.

lake did not meet parametric assumptions. Consequently, $p \mathrm{O}_{2}, p \mathrm{CO}_{2}$ and RI were correlated with chlorophyll $a$ and DOC concentrations using Spearman correlations (significance level set at $p<0.05$ ). All statistics were conducted using the software Statistica 7.0.

\section{Results}

Our study included the end of the rainy season in 2004 (March-April) followed by two dry periods in 2004 and 2005 

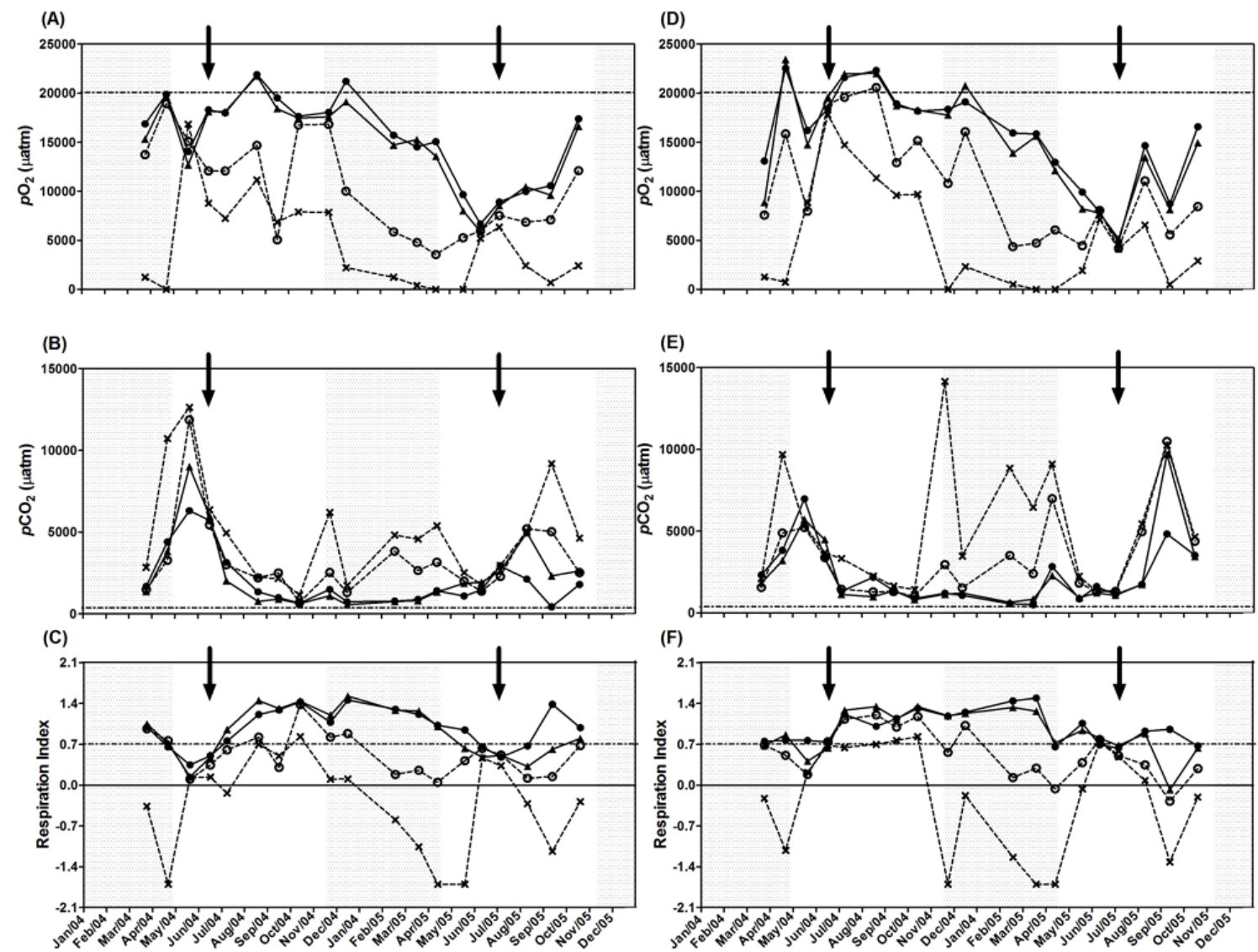

Fig. 3. Monthly fluctuations in $p \mathrm{O}_{2}$ (A and $\left.\mathbf{D}\right), p \mathrm{CO}_{2}(\mathbf{B}$ and $\mathbf{E})$ and respiration index $(\mathbf{C}$ and $\mathbf{F})$ in Lake Barra and Lake Aguapé, respectively, during 19 months from March 2004 to October 2005. Symbols, arrows and the dotted frame are as defined in Fig. 2. The dashed-dotted line represents the $p \mathrm{O}_{2}(\mathbf{A}$ and $\mathbf{D})$ or $p \mathrm{CO}_{2}(\mathbf{B}$ and $\mathbf{E})$ in equilibrium with the atmosphere and the critical limit for $\mathrm{RI}(\mathbf{C}$ and $\mathbf{F})$ to major aquatic organisms (Brewer and Peltzer, 2009). Negative values of RI indicate a ratio $p \mathrm{O}_{2}: p \mathrm{CO}_{2}<1.0$.

(May-October) with a whole rainy season between them (November 2004-April 2005; Fig. 2a). The dry season at the beginning of the winter (June-August 2004 and 2005) was characterized by lower water temperatures (around 23$24^{\circ} \mathrm{C}$ ) coupled to an overall thermal mixing in waters of both lakes (Fig. 2b and c). In contrast, the end of the dry season in 2004 and 2005 (September-October) showed an initial stratification in temperature, reaching $29^{\circ} \mathrm{C}$ in warmer surface waters and $26^{\circ} \mathrm{C}$ in those colder deep before a stronger thermal stratification during the rainy summer (December 2004March 2005), reaching 31 (surface) and $26^{\circ} \mathrm{C}$ (deep) in both lakes (Fig. 2b and c).

Lake Barra and Lake Aguapé showed similar fluctuations in $p \mathrm{O}_{2}, p \mathrm{CO}_{2}$ and RI during 19 months (Fig. 3), and non-significant differences for these variables comparing monthly (from March 2004 to October 2005) or 24-h cycle (in March, June and September 2005) measurements (Paired t-test, $\mathrm{p}<0.05$ ). In addition, non-significant difference was observed for gas fluxes between stratified and unstratified periods in both lakes (Paired t-test, $p<0.05$ ). From the end of the rainy seasons to the beginning of the dry winters in
2004 and 2005, $p \mathrm{O}_{2}$ and $\mathrm{RI}$ decreased in surface and increased in deep waters following the thermal mixing, while $p \mathrm{CO}_{2}$ showed the opposite trend, increasing in surface and decreasing in deep waters (Fig. 3). Additionally, a reversal increase in surface and decline in deep $p \mathrm{O}_{2}$ and RI followed the thermal stratification in both lakes during the end of the dry seasons and during the rainy summer in 2004 and 2005, also contrasting with the opposite trend observed for $p \mathrm{CO}_{2}$ (Fig. 3).

In this way, the stronger thermal stratification over the 24$\mathrm{h}$ cycle in the rainy summer (March 2005) was coupled to more intense differences for metabolic variables in the vertical profile, which showed, on average, $p \mathrm{O}_{2}$ values about 50-fold higher, $p \mathrm{CO}_{2}$ about six-fold lower, and RI around two-fold higher in surface (at 100 or $10 \%$ light penetration) than in deep (at $1 \%$ or $0 \%$ light penetration) waters of both lakes (Fig. 4; Tukey-Kramer, $p<0.05$ ). RI values were $\leq 0$ in deep waters of both lakes during this strong thermal stratification (Fig. 4). On the other hand, a persistent thermal mixing over the 24-h cycle at the beginning of the dry winter (June 2005) was related to non-significant differences for 

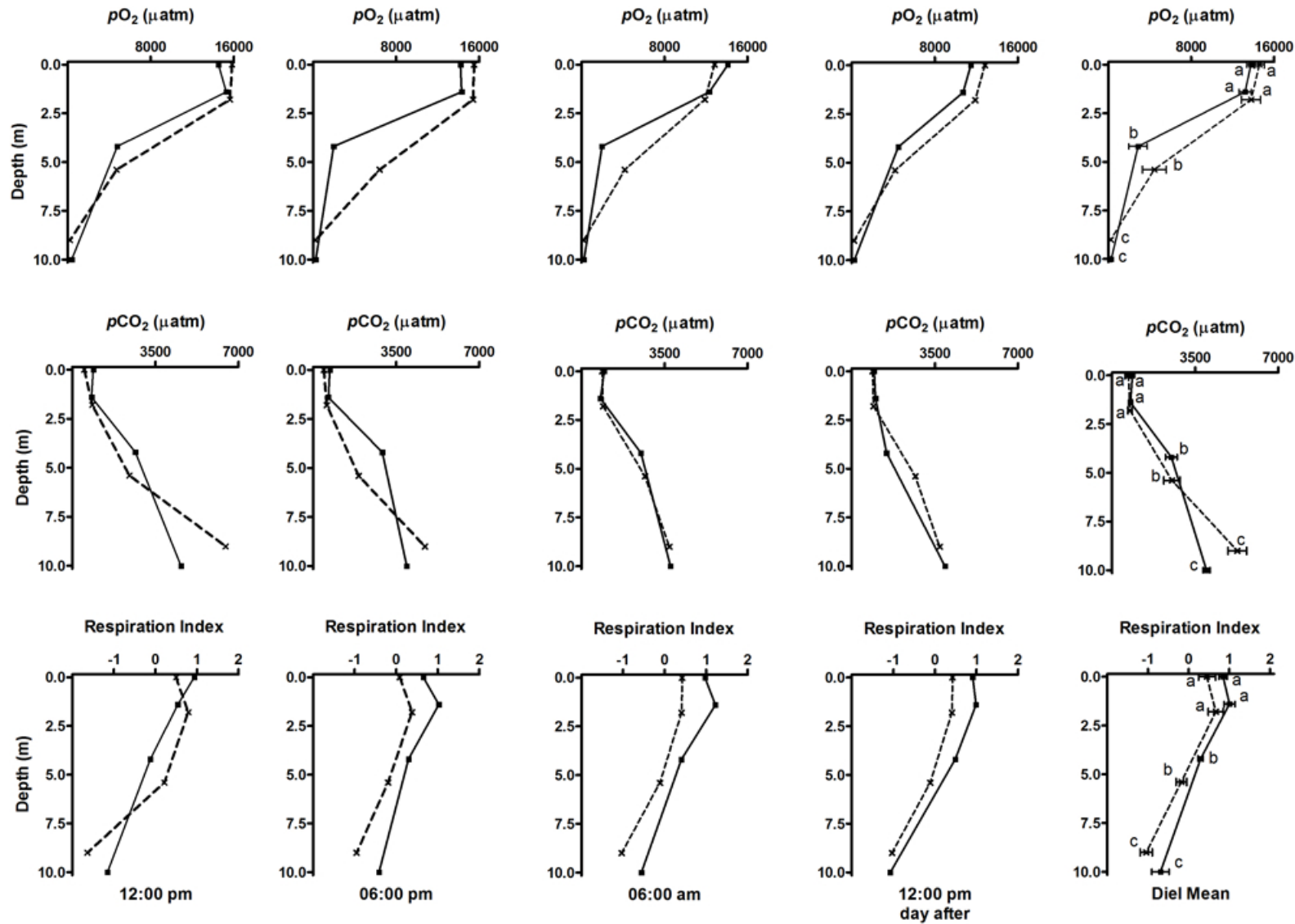

Fig. 4. Vertical profiles of daytime $p \mathrm{O}_{2}, p \mathrm{CO}_{2}$ and respiration index from the lake surface to deep waters for Lake Barra (unbroken line, filled squares) and Lake Aguapé (dashed line, crosses) during a thermal stratification event in the rainy season (March 2005). Values are the average \pm standard error (SE). The same letters indicate non-significant differences among treatments $(p<0.05$, Tukey-Kramer).

$p \mathrm{O}_{2}, p \mathrm{CO}_{2}$ and $\mathrm{RI}$ at both surface and deep depths (Fig. 5; repeated-measures one-way ANOVA, $p>0.05$ ). Lastly, the initial thermal stratification over the daily variation at the end of the dry season (September 2005) significantly showed, on average, $p \mathrm{O}_{2}$ about eight-fold higher, $p \mathrm{CO}_{2}$ about 2.5 -fold lower, and RI around two-fold higher comparing surface (100 or $10 \%$ light penetration) and deep ( $1 \%$ or $0 \%$ light penetration) waters of both lakes (Fig. 6; Tukey-Kramer, $p<0.05$ ), with RI values once again $\leq 0$ in the deep waters (Figs. 4 and $6)$.

Lake Aguapé showed significantly higher (almost twofold) chlorophyll $a$ and DOC concentrations, on average $( \pm \mathrm{SE}), 19.1( \pm 1.7) \mu \mathrm{g} \mathrm{l}^{-1}$ and $10.4( \pm 0.3) \mathrm{mgl}^{-1}$ respectively, than Lake Barra, on average $( \pm \mathrm{SE}), 12.0$ $( \pm 1.0) \mu \mathrm{gl}^{-1}$ and $5.5( \pm 0.2) \mathrm{mg} \mathrm{l}^{-1}$ respectively (Dunn, $p<0.05$ ). Any significant difference was not observed among sampling depths for DOC and chlorophyll $a$ in each lake (Dunn, $p>0.05$ ).

The negative relationship between $p \mathrm{O}_{2}$ and $p \mathrm{CO}_{2}$ was significant but weak for waters from Lake Barra and Lake Aguapé $\left(R_{\text {Spearman }}=-0.37\right.$ and -0.38 respectively; Spearman correlation, $p<0.05$ ). Additionally, $p \mathrm{O}_{2}, p \mathrm{CO}_{2}$ and RI in waters from all depths showed non-significant relationships with chlorophyll $a$ and DOC in both lakes (Spearman correlation, $p>0.05$ ), except weak significant correlations of $p \mathrm{O}_{2}$ with chlorophyll $a$ and DOC $\left(R_{\text {Spearman }}=0.33\right.$ and -0.23 , respectively $)$ or RI with chlorophyll $a\left(R_{\text {Spearman }}=\right.$ 0.17 ) in Lake Aguapé (Spearman correlations, $p<0.05$ ).

\section{Discussion}

Overall, Lake Barra and Lake Aguapé showed a consistent prevalence of $p \mathrm{CO}_{2}$ above and $p \mathrm{O}_{2}$ below the equilibrium with the atmosphere, resulting in low RI to aquatic organisms. The persistence of $\mathrm{CO}_{2}$ emissions to the atmosphere during the study reached, on average $( \pm S E), 27.6$ ( \pm 3.6$) \mathrm{mg} \mathrm{C} \mathrm{m}^{-2} \mathrm{~h}^{-1}$ (assuming air-water fluxes calculated as Cole and Caraco, 1998, a $p \mathrm{CO}_{2}$ in equilibrium with the atmosphere of $380 \mu \mathrm{atm}$ and a mean $10-\mathrm{m}$ wind speed over land of $3.28 \mathrm{~m} \mathrm{~s}^{-1}$; Archer and Jacobson, 2005). Using the conservative wind velocity applied in other studies of $0.5 \mathrm{~m} \mathrm{~s}^{-1}$ (Cole et al 1994), the average $\mathrm{CO}_{2}$ efflux calculated for lakes Barra and Aguapé was $17.4 \mathrm{mg} \mathrm{C} \mathrm{m}^{-2} \mathrm{~h}^{-1}$, 

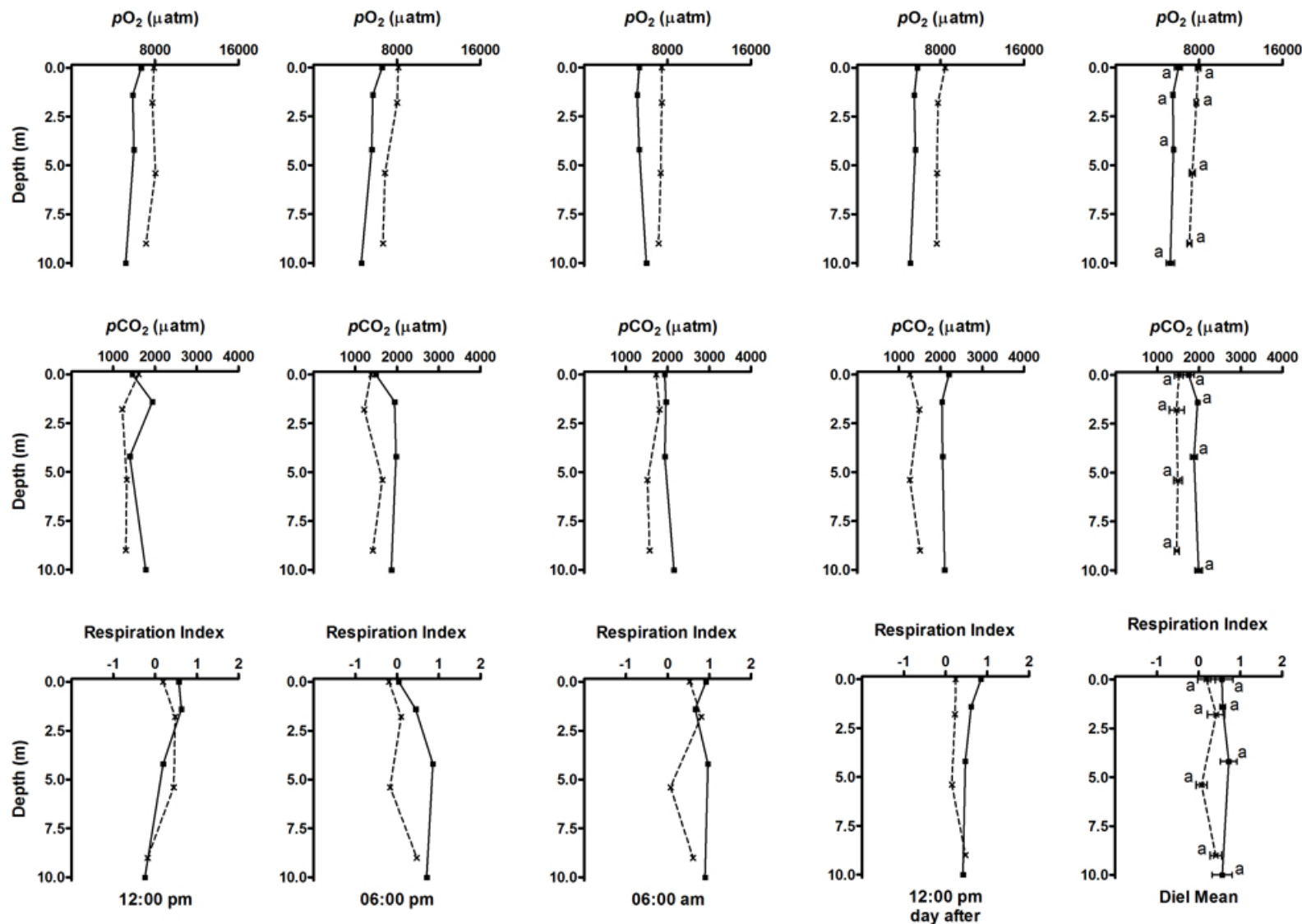

Fig. 5. Vertical profiles of daytime $p \mathrm{O}_{2}, p \mathrm{CO}_{2}$ and respiration index from the lake surface to deep waters for both lakes during a thermal mixing event in the dry winter (June 2005). Values are the average \pm SE. Symbols and letters are as defined in Fig. 4.

which is comparable to the average reported for 367 tropical lakes (20.1 $\mathrm{mg} \mathrm{C} \mathrm{m}^{-2} \mathrm{~h}^{-1}$ ) (Marotta et al., 2009). This confirms that the typical role of terrestrial $\mathrm{C}$ inputs subsiding the biological degradation and $\mathrm{CO}_{2}$ supersaturation in organicenriched waters (Marotta et al., 2012) or in most lakes around the world (Cole et al., 1994, 2007; Duarte and Prairie, 2005) might be also found in inland waters of the Atlantic Tropical Forest.

Indeed, the negative relationship between $p \mathrm{O}_{2}$ and $p \mathrm{CO}_{2}$ also supported the potential role of the balance between aquatic respiration and photosynthesis in regulating the production and consumption of metabolic gases in waters of both lakes studied here. This was confirmed in the lake with higher chlorophyll $a$ and DOC concentrations (Lake Aguapé), as expected significant relationships were found between chlorophyll $a$ (algal biomass) and increases in $\mathrm{O}_{2}$ and RI, probably from oxygenic photosynthesis (Carignan et al., 2000). However, all these significant correlations were weak, coupled to other non-significant relationships between chlorophyll $a$ or DOC with $p \mathrm{O}_{2}, p \mathrm{CO}_{2}$ or RI in Lake Barra and Lake Aguapé. These weakly significant and non-significant correlations suggest that dynamics other than the balance between aquatic photosynthesis and respiration might drive high fluctuations in metabolic gases, strongly reducing the negative relationship between metabolic gases, $p \mathrm{O}_{2}$ and $p \mathrm{CO}_{2}$, in both lakes. The $\mathrm{C}$ inputs from the watershed (Marotta et al., 2010b), and anaerobic (Conrad et al., 2011) or physical-chemical (Amado et al., 2007) organic degradation processes may enhance $\mathrm{CO}_{2}$ without consuming $\mathrm{O}_{2}$ in natural waters. In addition, anoxygenic photosynthesis may be responsible for the decoupling between $\mathrm{CO}_{2}$ fixation and $\mathrm{O}_{2}$ production (Fontes et al., 2011). After the aerobic organic degradation reducing $\mathrm{O}_{2}$ supply (VaquerSunyer and Duarte, 2008; Sobek et al., 2009), intense anaerobic pathways subsidized by high allochthonous organic inputs may decrease RI to negative values $(\mathrm{RI} \leq 0)$ (Brewer and Peltzer, 2009) or release toxic compounds (Diaz and Rosenberg, 2008) to critical levels to major organisms in aquatic ecosystems.

The prevalence of high $p \mathrm{CO}_{2}$ and low $p \mathrm{O}_{2}$ also revealed highly dynamic fluctuations in metabolic gases and RI in waters of both lakes during 19 months. Substantial changes in $p \mathrm{CO}_{2}, p \mathrm{O}_{2}$ and $\mathrm{RI}$ were closely related to seasonal patterns of water stratification and mixing. Natural shifts from stratified and anoxic to oxic and mixed conditions were observed throughout the year in deep waters of both lakes. On the other 

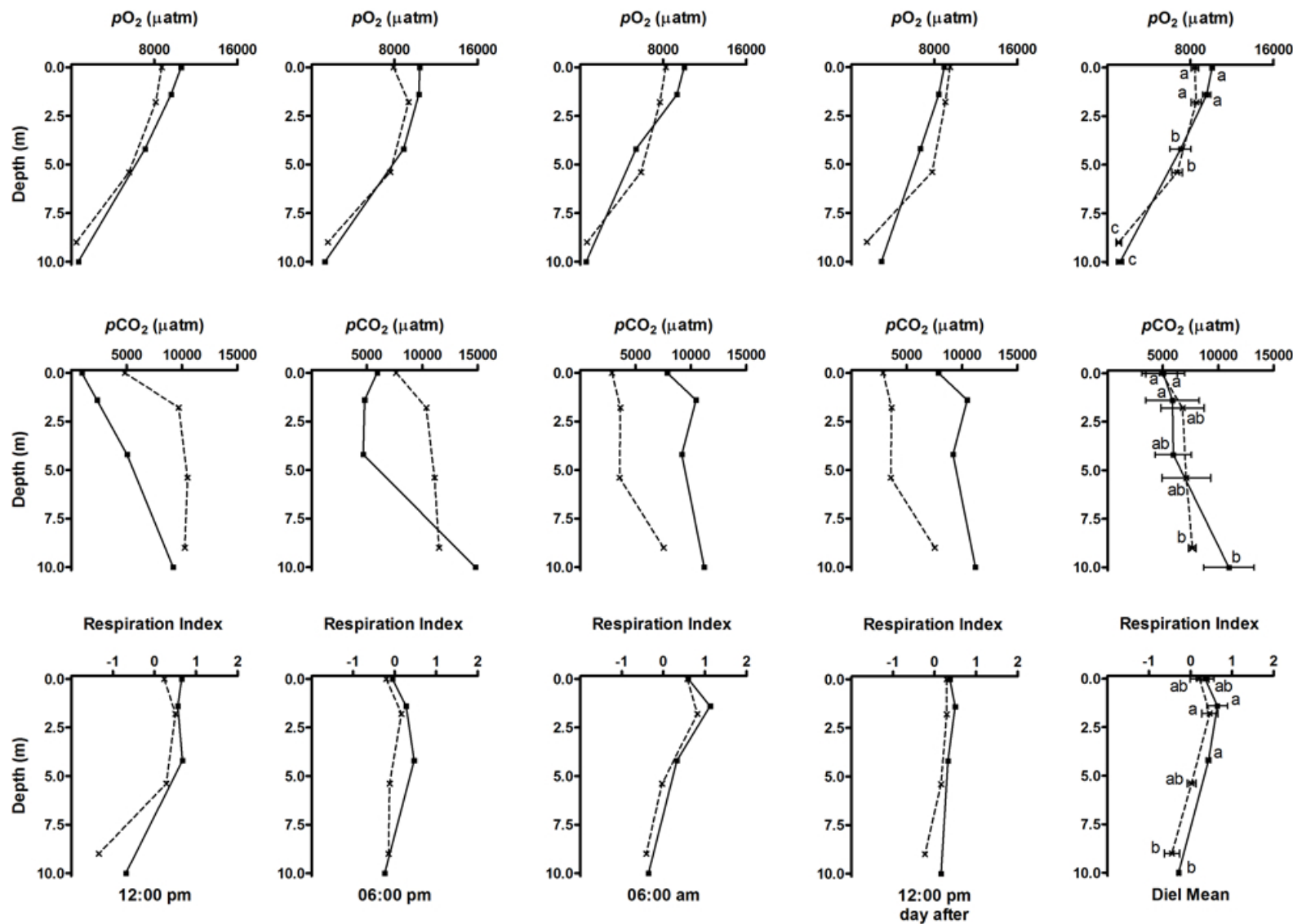

Fig. 6. Vertical profiles of daytime $p \mathrm{O}_{2}, p \mathrm{CO}_{2}$ and respiration index from the lake surface to deep waters for both lakes during initial thermal stratification events at the end of the dry season (September 2005). Values are the average \pm SE. Symbols and letters are as defined in Fig. 4.

hand, surface waters showed a contrasting decline in $\mathrm{O}_{2}$ and RI following the mixing with deep waters during a mixing period at the beginning of the dry winter. Higher temperatures in the summer stimulating biological activity (Brown et al., 2004; Clarke and Fraser, 2004) might explain more intense increases reported here for $\mathrm{O}_{2}$ and $\mathrm{RI}$ in the surface photic zone, probably by primary producers, and stronger decreases for both $\left(\mathrm{O}_{2}\right.$ and $\left.\mathrm{RI}\right)$ in deep waters, probably by light limitation to oxygenic photosynthesis (Gu et al., 2011; Fontes et al., 2011). These results confirm the high temporal variability of metabolic gases described in previous studies on tropical lake waters, which related typical warmer temperatures at low latitudes to large shifts in biological processes, following common changes in meteorological and physicalchemical conditions over time (Marotta et al., 2010b, a).

In conclusion, we confirm the hypothesis, as thermal stratification events were coupled to hypoxia, reaching anoxia in deep waters of both studied lakes. Indeed, our results consistently suggest a natural susceptibility of deep waters in oligotrophic lakes of the Atlantic Tropical Forest to anoxia and low RI (reaching values $<0$ ) mainly during the summer. These conditions in aquatic ecosystems typically result in low biological diversity (Brewer and Peltzer, 2009; Diaz and Rosenberg, 2008; Vaquer-Sunyer and Duarte, 2008) and high production of $\mathrm{CO}_{2}$ and other more powerful greenhouse gases (Conrad et al., 2011; Bastviken et al., 2011). Here, the natural water mixing during the beginning of the dry winter showed a reversal oxygenation and increase of RI in deep waters, coupled to the opposite trend at the surface without reaching severe hypoxia throughout the water column. This illustrates that tropical lakes could be very dynamic, but also especially sensitive to organic inputs, which are commonly intensified by human activities in the watershed, like from untreated discharges of sewage and animal manure (Downing and McCauley, 1992). Natural events of anoxia under warm temperatures in tropical waters indicate, therefore, that human-induced organic inputs could potentially contribute to persistence of low $\mathrm{O}_{2}$ supply and $\mathrm{RI}$ resulting in $\mathrm{CO}_{2}$ evasion to the atmosphere. Studies on the fluctuations of metabolic gases, like $\mathrm{O}_{2}$ and $\mathrm{CO}_{2}$, related to hypoxia at low latitudes are crucial to a better knowledge on the controls and feedbacks of two relevant topics that are often intensified by human activities in broad areas, the organism's death and greenhouse gas emissions in aquatic ecosystems. 
Acknowledgements. We thank André Luiz dos Santos Furtado from the Brazilian Agricultural Research Corporation (EMBRAPA) for the satellite image in Fig. 1.

Edited by: S. Pantoja

\section{References}

Amado, A. M., Cotner, J. B., Suhett, A. L., Esteves, F. D., Bozelli, R. L., and Farjalla, V. F.: Contrasting interactions mediate dissolved organic matter decomposition in tropical aquatic ecosystems, Aqua. Micro. Ecol., 49, 25-34, 2007.

Amarasinghe, U. S. and Welcomme, R. L.: An analysis of fish species richness in natural lakes, Environ. Biol. Fish., 65, 327339, doi:10.1023/a:1020558820327, 2002.

APHA: Standard methods for the examination of water and wastewater, 18th Edn., American Public Health Association, Washington, DC, 1992.

Archer, C. L. and Jacobson, M. Z.: Evaluation of global wind power, J. Geophys. Res., 110, D12110, doi:10.1029/2004jd005462, 2005.

Bastviken, D., Santoro, A. L., Marotta, H., Pinho, L. Q., Calheiros, D. F., Crill, P., and Enrich-Prast, A.: Methane emissions from pantanal, south america, during the low water season: Toward more comprehensive sampling, Environ. Sci. Technol., 44, 54505455, doi:10.1021/es1005048, 2010.

Bastviken, D., Tranvik, L. J., Downing, J. A., Crill, P. M., and Enrich-Prast, A.: Freshwater methane emissions offset the continental carbon sink, Science, 331, 50, doi:10.1126/science.1196808, 2011.

Biddanda, B., Ogdahl, M., and Cotner, J.: Dominance of bacterial metabolism in oligotrophic relative to eutrophic waters, Limnol. Oceanog., 46, 730-739, 2001.

Brewer, P. G. and Peltzer, E. T.: Limits to marine life, Science, 324, 347-348, doi:10.1126/science.1170756, 2009.

Brown, J. H., Gillooly, J. F., Allen, A. P., Savage, V. M., and West, G. B.: Toward a metabolic theory of ecology, Ecology, 85, 17711789, 2004.

Carignan, R., Planas, D., and Vis, C.: Planktonic production and respiration in oligotrophic shield lakes, Limnol. Oceanogr., 45, 189-199, 2000.

Clarke, A. and Fraser, K. P. P.: Why does metabolism scale with temperature?, Funct. Ecol., 18, 243-251, doi:10.1111/j.02698463.2004.00841.x, 2004.

Cole, J. J., Caraco, N. F., Kling, G. W., and Kratz, T. K.: Carbondioxide supersaturation in the surface waters of lakes, Science, 265, 1568-1570, 1994.

Cole, J. J., Pace, M. L., Carpenter, S. R., and Kitchell, J. F.: Persistence of net heterotrophy in lakes during nutrient addition and food web manipulations, Limnol. Oceanogr., 45, 1718-1730, 2000.

Cole, J. J., Prairie, Y. T., Caraco, N. F., McDowell, W. H., Tranvik, L. J., Striegl, R. G., Duarte, C. M., Kortelainen, P., Downing, J. A., Middelburg, J. J., and Melack, J.: Plumbing the global carbon cycle: Integrating inland waters into the terrestrial carbon budget, Ecosystems, 10, 171-184, 2007.

Conrad, R., Noll, M., Claus, P., Klose, M., Bastos, W. R., and Enrich-Prast, A.: Stable carbon isotope discrimination and microbiology of methane formation in tropical anoxic lake sedi- ments, Biogeosciences, 8, 795-814, doi:10.5194/bg-8-795-2011, 2011.

Davidson, E. A. and Janssens, I. A.: Temperature sensitivity of soil carbon decomposition and feedbacks to climate change, Nature, 440, 165-173, 2006.

Diaz, R. J. and Rosenberg, R.: Spreading dead zones and consequences for marine ecosystems, Science, 321, 926-929, doi:10.1126/science.1156401, 2008.

Downing, J. A., and McCauley, E.: The nitrogen - phosphorus relationship in lakes, Limnol. Oceanogr., 37, 936-945, 1992.

Downing, J. A., Prairie, Y. T., Cole, J. J., Duarte, C. M., Tranvik, L. J., Striegl, R. G., McDowell, W. H., Kortelainen, P., Caraco, N. F., Melack, J. M., and Middelburg, J. J.: The global abundance and size distribution of lakes, ponds, and impoundments, Limnol. Oceanogr., 51, 2388-2397, 2006.

Downing, J. A., Cole, J. J., Middelburg, J. J., Striegl, R. G., Duarte, C. M., Kortelainen, P., Prairie, Y. T., and Laube, K. A.: Sediment organic carbon burial in agriculturally eutrophic impoundments over the last century, Global Biogeochem. Cy., 22, GB1018, doi:10.1029/2006gb002854, 2008.

Duarte, C. M. and Prairie, Y. T.: Prevalence of heterotrophy and atmospheric $\mathrm{CO}_{2}$ emissions from aquatic ecosystems, Ecosystems, 8, 862-870, 2005.

Fontes, M. L. S., Suzuki, M. T., Cottrell, M. T., and Abreu, P. C.: Primary production in a subtropical stratified coastal lagooncontribution of anoxygenic phototrophic bacteria, Micro. Ecol., 61, 223-237, doi:10.1007/s00248-010-9739-x, 2011.

Garcia, H. E. and Gordon, L. I.: Oxygen solubility in seawater - better fitting equations, Limnol. Oceanogr., 37, 1307-1312, 1992.

Gu, B., Schelske, C. L., and Waters, M. N.: Patterns and controls of seasonal variability of carbon stable isotopes of particulate organic matter in lakes, Oecologia, 165, 1083-1094, doi:10.1007/s00442-010-1888-6, 2011.

Howarth, R. W., Schneider, R., and Swaney, D.: Metabolism and organic carbon fluxes in the tidal freshwater hudson river, Estuaries, 19, 848-865, 1996.

Lorenzen, C. J.: Determination of chlorophyll and pheo-pigments spectrophotometric equations, Limnol. Oceanogr., 12, 343-346, 1967.

Marotta, H., Duarte, C. M., Sobek, S., and Enrich-Prast, A.: Large $\mathrm{CO}_{2}$ disequilibria in tropical lakes, Global Biogeochem. Cy., 23, Gb4022, doi:10.1029/2008gb003434, 2009a.

Marotta, H., Paiva, L. T., and Petrucio, M. M.: Changes in thermal and oxygen stratification pattern coupled to persistence of $\mathrm{CO}_{2}$ outgassing in shallow lakes of the surroundings of Atlantic Tropical Forest, Brazil, Limnology, 10, 195-202, doi:10.1007/s10201009-0272-x, 2009b.

Marotta, H., Duarte, C. M., Meirelles-Pereira, F., Bento, L., Esteves, F. A., and Enrich-Prast, A.: Long-term variability of $\mathrm{CO}_{2}$ in two shallow tropical lakes experiencing episodic eutrophication and acidification events, Ecosystems, 13, 382-392, doi:10.1007/s10021-010-9325-6, 2010a.

Marotta, H., Duarte, C. M., Pinho, L., and Enrich-Prast, A.: Rainfall leads to increased $p \mathrm{CO}_{2}$ in Brazilian coastal lakes, Biogeosciences, 7, 1607-1614, doi:10.5194/bg-7-1607-2010, 2010 b.

Marotta, H., Duarte, C. M., Guimaraes-Souza, B. A., and EnrichPrast, A.: Synergistic control of $\mathrm{CO}_{2}$ emissions by fish and nutrients in a humic tropical lake, Oecologia, 168, 839-847, doi:10.1007/s00442-011-2131-9, 2012. 
Metzker, T., Sposito, T. C., Martins, M. T. F., Horta, M. B., and Garcia, Q. S.: Forest dynamics and carbon stocks in rio doce state park - an atlantic rainforest hotspot, Curr. Sci., 100, 1855-1862, 2011.

Pace, M. L., Cole, J. J., Carpenter, S. R., Kitchell, J. F., Hodgson, J. R., Van de Bogert, M. C., Bade, D. L., Kritzberg, E. S., and Bastviken, D.: Whole-lake carbon-13 additions reveal terrestrial support of aquatic food webs, Nature, 427, 240-243, 2004.

Peel, M. C., Finlayson, B. L., and McMahon, T. A.: Updated world map of the Köppen-Geiger climate classification, Hydrol. Earth Syst. Sci., 11, 1633-1644, doi:10.5194/hess-11-16332007, 2007.

Petrucio, M. M. and Barbosa, F. A. R.: Diel variations of phytoplankton and bacterioplankton production rates in four tropical lakes in the middle rio doce basin (southeastern brazil), Hydrobiologia, 513, 71-76, 2004.

Petrucio, M. M., Barbosa, F. A. R., and Furtado, A. L. S.: Bacterioplankton and phytoplankton production in seven lakes in the middle rio doce basin, south-east brazil, Limnologica, 36, 192203, 2006.

Sobek, S., Durisch-Kaiser, E., Zurbrugg, R., Wongfun, N., Wessels, M., Pasche, N., and Wehrli, B.: Organic carbon burial efficiency in lake sediments controlled by oxygen exposure time and sediment source, Limnol. Oceanogr., 54, 2243-2254, 2009.

Stumm, W. and Morgan, J. J.: Aquatic chemistry:Chemical equilibria and rates in natural waters, 3rd Edn., Wiley-Interscience, New York, 88 pp., 1996.
Tranvik, L. J., Downing, J. A., Cotner, J. B., Loiselle, S. A., Striegl, R. G., Ballatore, T. J., Dillon, P., Finlay, K., Fortino, K., Knoll, L. B., Kortelainen, P. L., Kutser, T., Larsen, S., Laurion, I., Leech, D. M., McCallister, S. L., McKnight, D. M., Melack, J. M., Overholt, E., Porter, J. A., Prairie, Y., Renwick, W. H., Roland, F., Sherman, B. S., Schindler, D. W., Sobek, S., Tremblay, A., Vanni, M. J., Verschoor, A. M., von Wachenfeldt, E., and Weyhenmeyer, G. A.: Lakes and reservoirs as regulators of carbon cycling and climate, Limnol. Oceanogr., 54, 2298-2314, 2009.

Tundisi, J. G.: A note on the effect of rainfall in the process of stratification and stability in the rio doce lakes, in: Limnological studies on the rio doce valley lakes, brazil, edited by: Tundisi, J. G. and Saijo, Y., Brazilian Academy of Sciences, São Carlos, 7982, 1997.

Vaquer-Sunyer, R., and Duarte, C. M.: Thresholds of hypoxia for marine biodiversity, Proc. Nat. Aca. Sci., 105, 15452-15457, doi:10.1073/pnas.0803833105, 2008.

von Wachenfeldt, E. and Tranvik, L. J.: Sedimentation in boreal lakes - the role of flocculation of allochthonous dissolved organic matter in the water column, Ecosystems, 11, 803-814, doi:10.1007/s10021-008-9162-z, 2008.

Weiss, R. F.: Carbon dioxide in water and seawater: The solubility of a non-ideal gas, Mar. Chem., 2, 203-215, 1974.

Zar, J. H.: Biostatistical analysis, 3r Edn., Prentice Hall, New Jersey, 1996. 